\title{
Research Paper \\ The Effectiveness of Psychosocial Program on Speed and Accuracy of Information Processing in Students with Sluggish Cognitive Tempo (SCT)
}

\section{Leyla Hamivand ${ }^{1}$, Hamid Alizadeh ${ }^{* 2}$, Norali Farohki ${ }^{3}$, Farangis Kazemi ${ }^{4}$}

1. Ph.D. in Psychology and Education of Exceptional Students, Faculty of Psychology and Educational Sciences, Allameh Tabataba'i University, Tehran, Iran

2. Professor, Department of Psychology and Education of Exceptional Students, Faculty of Psychology and Educational Sciences, Allameh Tabataba'i University, Tehran, Iran

3. Associate Professor, Department of Assessment and Measurement, Faculty of Psychology and Educational Sciences, Allameh Tabataba'i University, Tehran, Iran

4. Associate Professor, Department of Psychology and Education of Exceptional Students, Faculty of Psychology and Educational Sciences, Allameh Tabataba'i University, Tehran, Iran

Citation: Hamivand L, Alizadeh H, Farohki N, Kazemi F. The effectiveness of psychosocial program on speed and accuracy of information processing in students with sluggish cognitive tempo (sct). Quarterly Journal of Child Mental Health. 2020; 7(2): $108-119$.

http://dx.doi.org/10.29252/jcmh.7.2.10

\section{A R T I C L E I N F O}

\section{Keywords:}

Psycho-social program, sluggish cognitive tempo, speed and accuracy of information processing

Received: 19 May 2018 Accepted: 3 Sep 2018 Available: 21 Sep 2020

\section{A B S T R A C T}

Background and Purpose: Sluggish cognitive tempo (SCT) includes a series of symptoms used to describe a special type of attention- concentration disorder and slow information processing. Present study was done to investigate the effectiveness of psychosocial program on the speed and accuracy of information processing in children with SCT.

Method: This study was a quasi-experimental research with pretest-posttest control group design. The study population included all the 9 to 12 -year old students with symptoms of SCT who were studying at the public schools of Tehran in the academic year 2016-2017. A sample of 60 students with SCT was selected by convenience sampling and then randomly assigned to either the experimental or control group. Slugging Cognitive Tempo Scale (Boronz, 2019) was used to identify these students and the d2 Test of Attention (Brickenkamp, 1981) was used to assess the speed and accuracy of information processing. The experimental group received eight 60 -min sessions of psychosocial program, while the control group underwent no intervention. Data were analyzed by MANCOVA.

Results: Findings showed that there was a significant difference in the mean score of the experimental and control group in terms of speed and accuracy of information processing $(F=32.4$, $\mathrm{P}<0.001)$ and scores of the experimental group increased compared to the control group in the posttest stage.

Conclusion: Based on the results of this study, it can be concluded that the psychosocial program can increase the speed and accuracy of information processing and thus it can significantly reduce the behavioral and academic problems of children with SCT.

\footnotetext{
* Corresponding author: Hamid Alizadeh, Professor, Department of Psychology and Education of Exceptional Students, Faculty of Psychology and Educational Sciences, Allameh Tabataba'i University, Tehran, Iran.

E-mail addresses: Alizadeh@atu.ac.ir
} 


\section{اثربخشى برنامه مداخله روانى- اجتماعى بر سرعت و دقت يردازش اطلاعات دانش آموزان داراى ضرب آهنك شناختى كند}

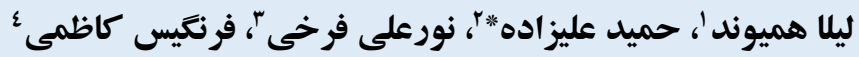

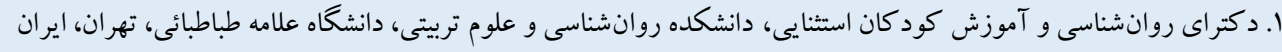

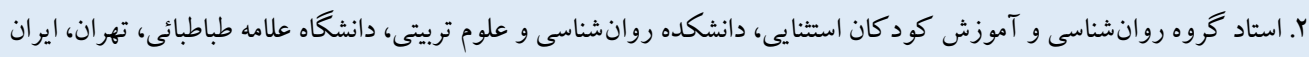

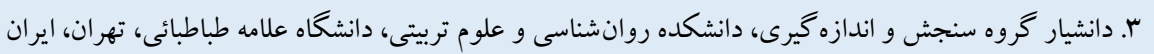

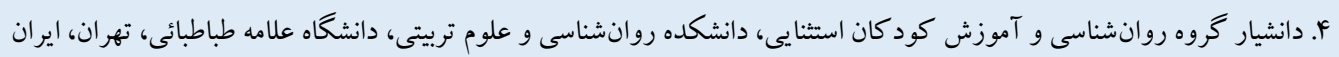

\section{جكيده}

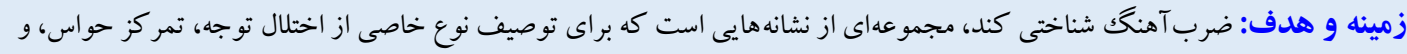

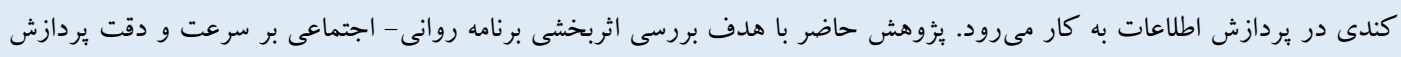
اطلاعات دانش آموزان داراى ضرب آهنك شناختى كند انجام شد.

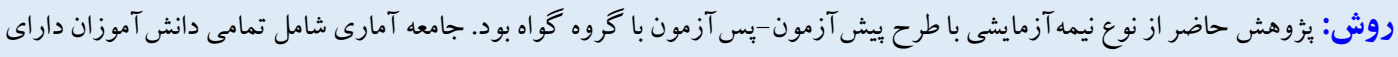

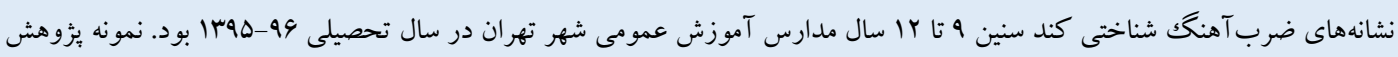

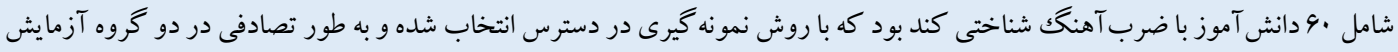

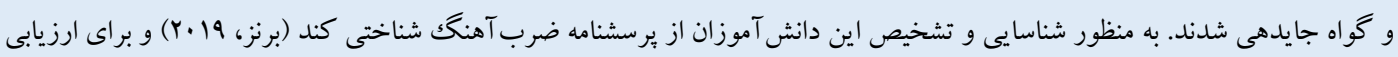

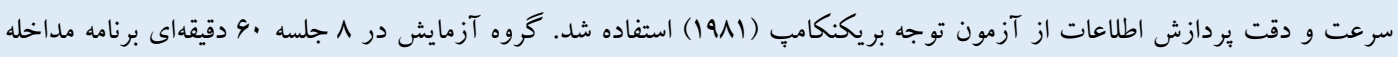

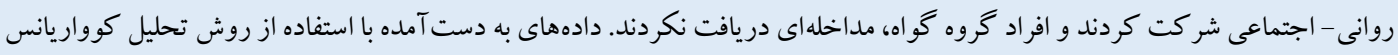
جند متغيرى تجزيه و تحليل شد.

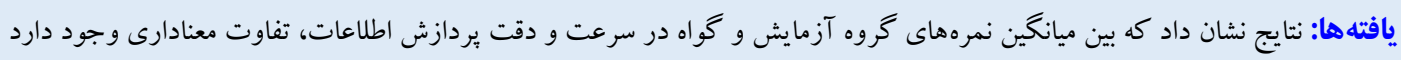

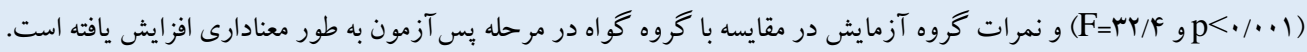

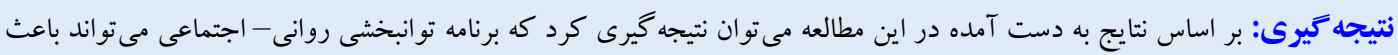

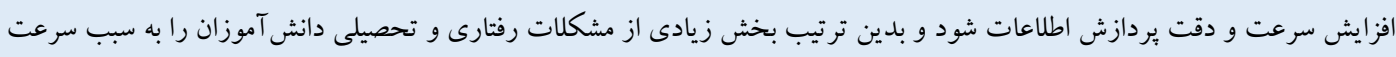

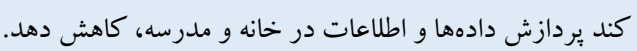

مشخصات مقاله

كليدوازهها:

مداخله روانى - اجتماعى، مليدا:

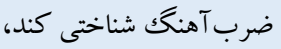
سرعت و دقت بردازش اطلاعات

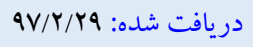

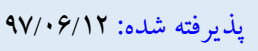
منتشر شده:

* نويسنده مسئول: حميد عليزاده، استاد گروه روانشناسى و آموزش كود كان استنايى، دانشكده روانشناسى و علوم تربيتى، دانشكاه علامه طباطبائى، تهران، ايران.

راياناهם: Alizadeh@atu.ac.ir

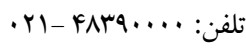




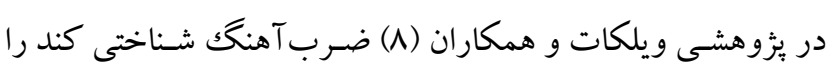

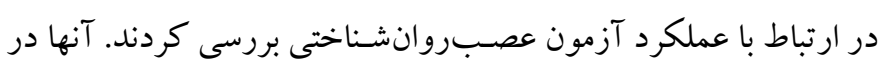

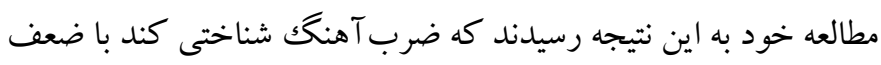

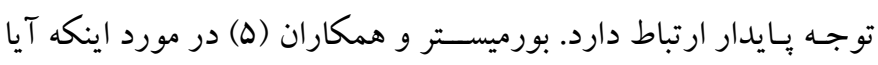

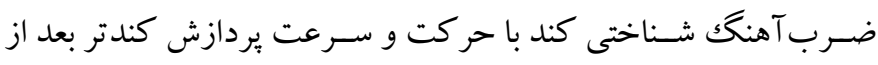

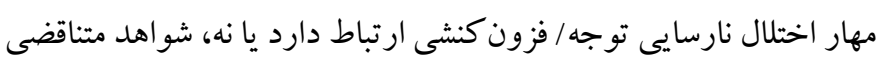

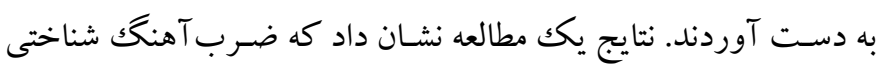
كند با تغييريذيرى عملكرد حافظه فضايى، ارتباط دارد (9). آراجو جيمنز

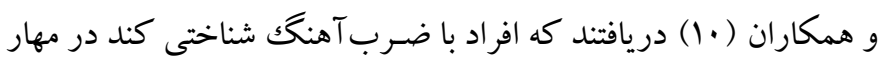

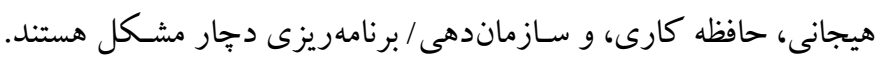

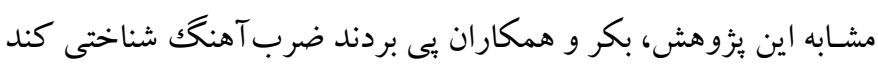

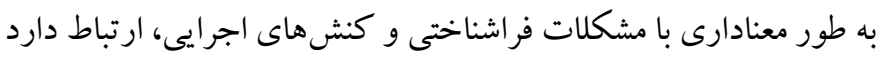

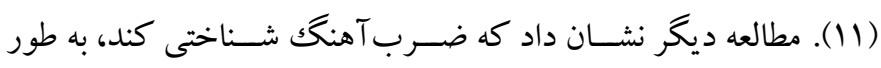

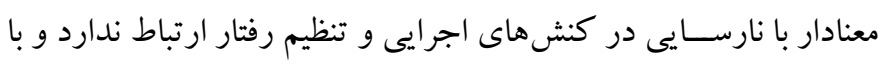

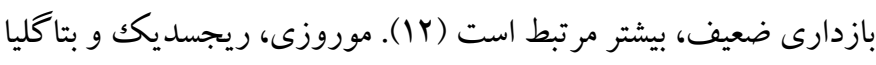
(r) بيان كردند كه اين افراد در حافظه كارى مشكل دارند.

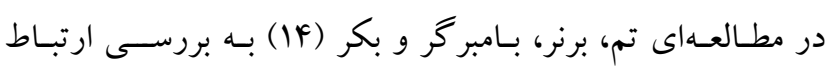

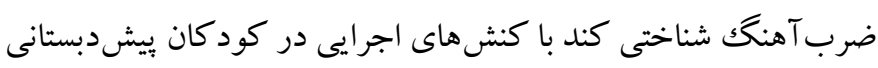

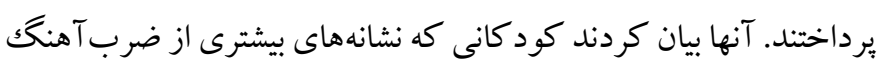

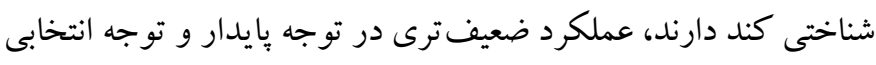

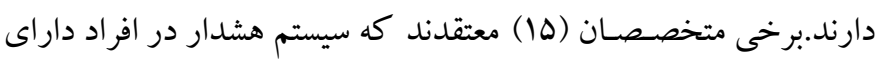
ضرب آهنك شناختى كند، ممكن است آسيب ديده باشد. اين آسيبها

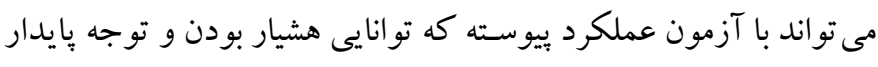

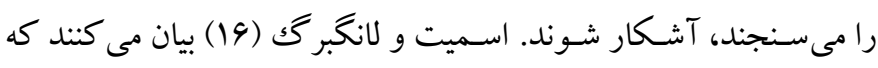

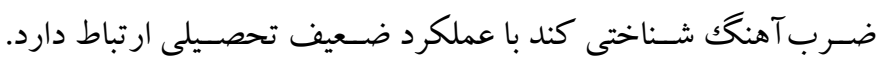

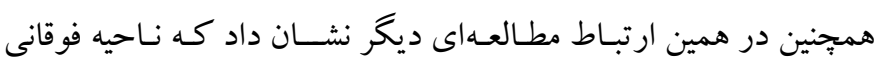

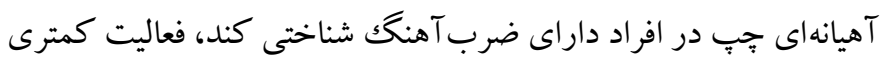

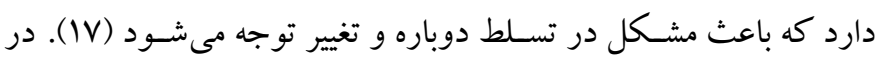

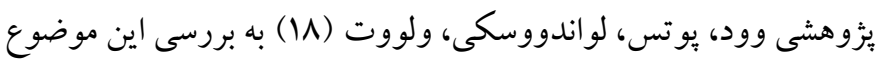

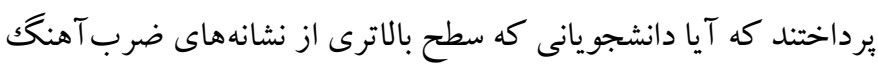

1. Sluggish cognitive tempo

2. Attention deficit hyperactivity disorder
مقلهم ضـربآهنگك شـناختى كند'، بيانگر مجموعهاى از نشـانههايى اسـت كه

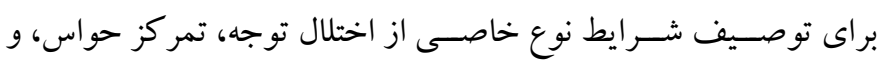

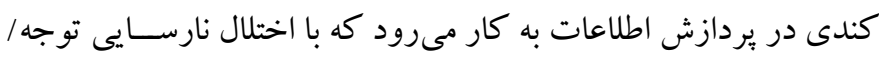

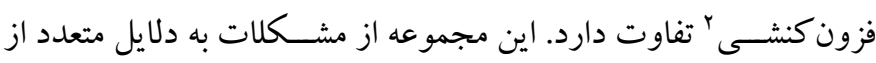

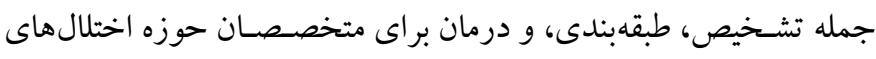

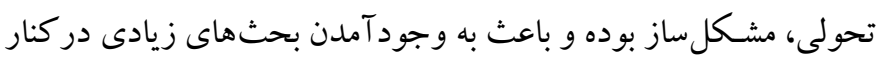

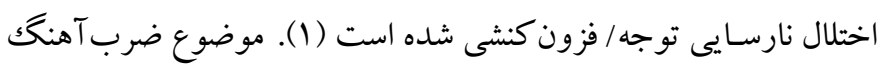

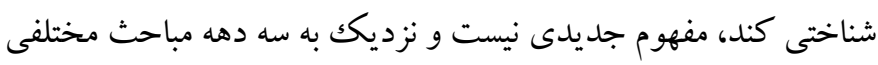

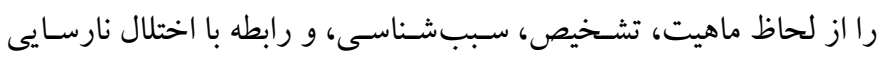

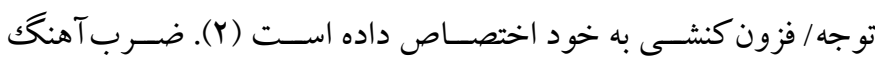

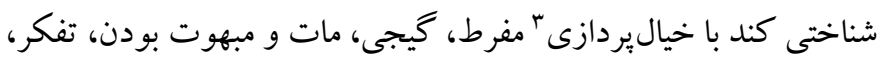

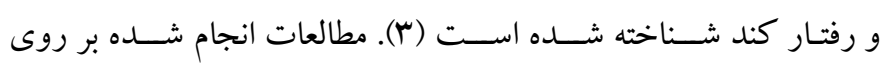
ضرب آهنك شناختى كند از اين ديد كاه حمايت مى كنند كه اين اختلال

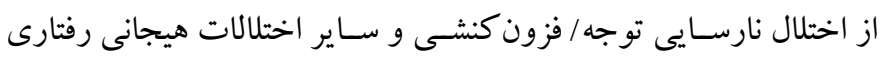

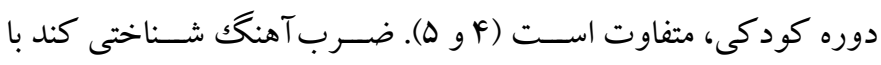

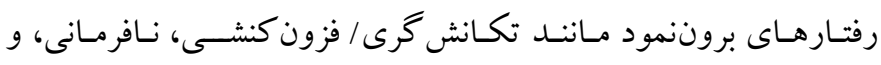

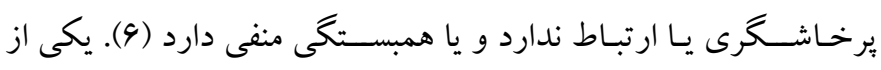

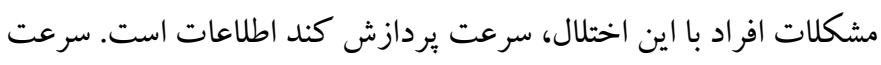

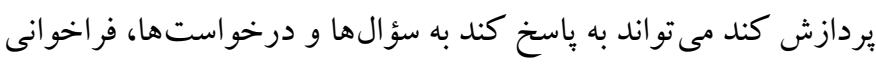
از حافظه ضعيف، و تكميل كند تكاليف، منجر شود. وقتى اين مشكلات

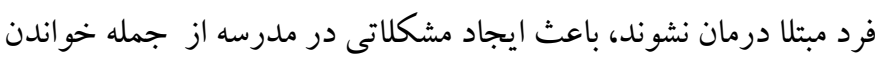

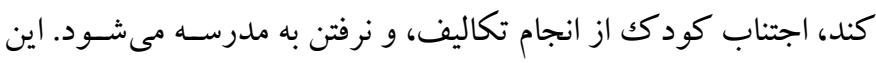

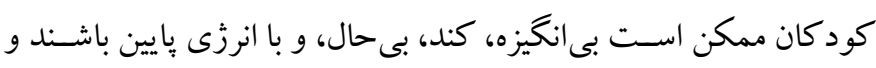

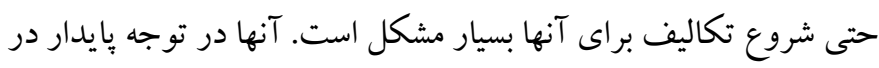

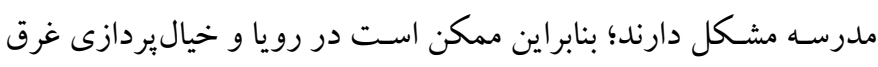

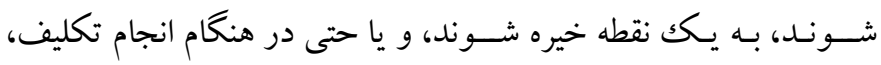

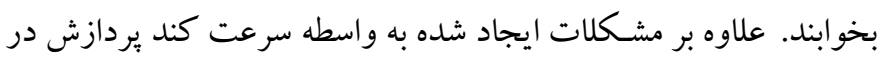

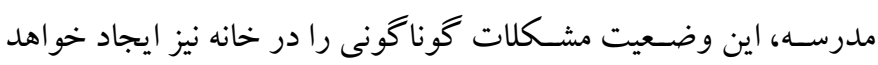

كرد (V) 
كود كان با اختلال نارسـايى توجه همر اه با ضرب آهنگك شناختى كند از درمانهايى براى نقص بردازش و آسيب اجتماعى سود مىبرند (YF).

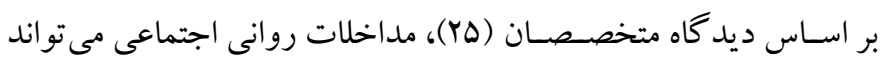

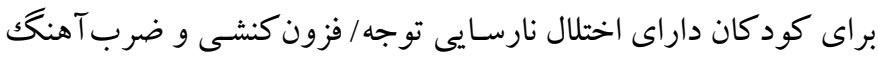

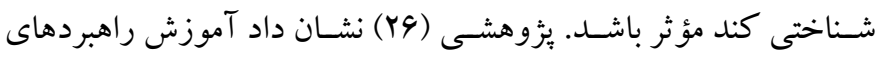
تكميل تكليف مى تواند بر افزايش سرعت و دقت يردازش اطلاعات مؤثر

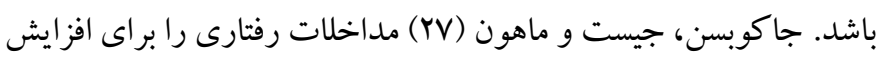

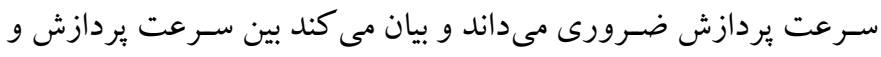

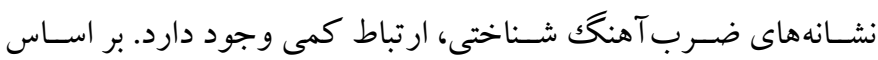

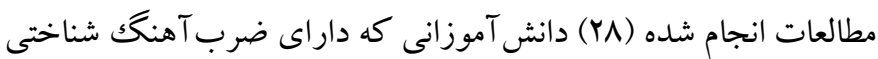

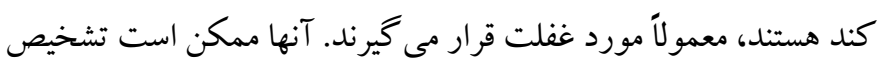

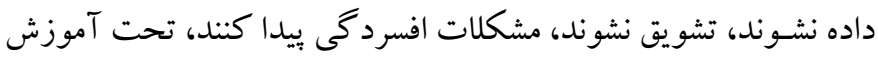

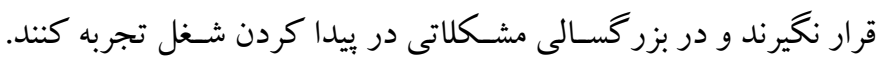

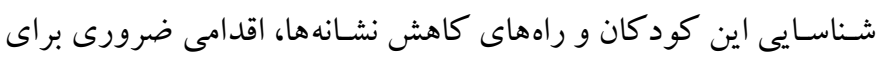

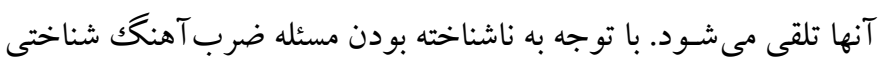

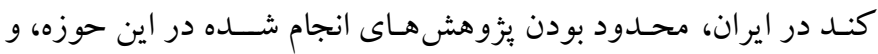

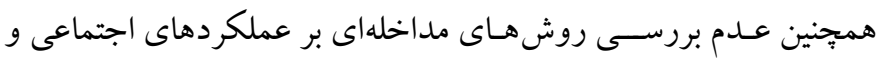

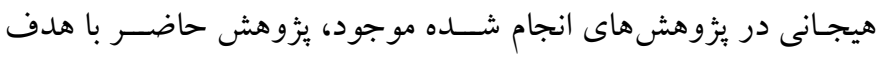
بررسى اثربخشى مداخله روانى - اجتماعى بر سـرعت و دقت يردازش اطلاعات دانش آموزان داراى ضرب آهنگك شناختى كند انجام شد. روسي

روش

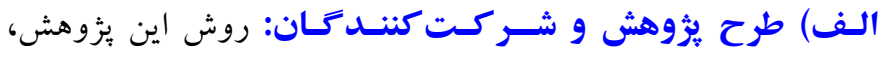

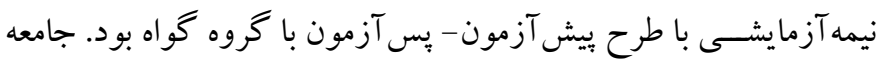

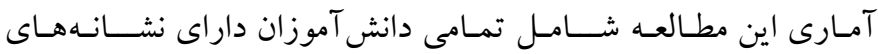

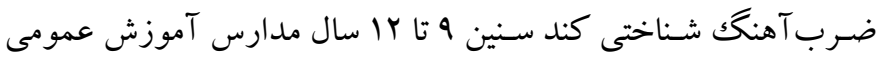

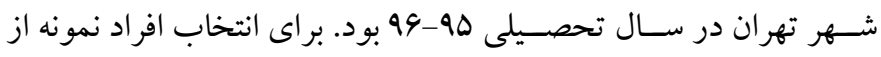

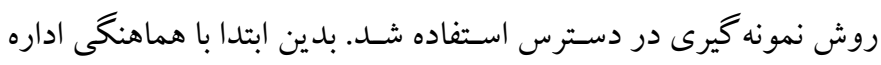

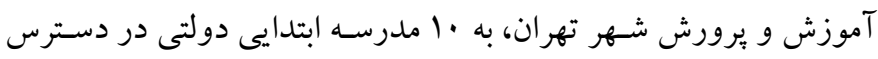

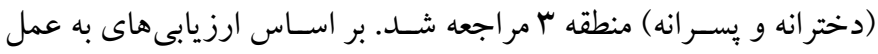

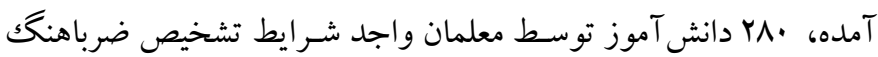

شـناختى كند را كزارش مى كنند، در انجام تكاليف شــناختى و عملكرد

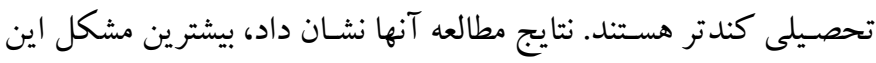

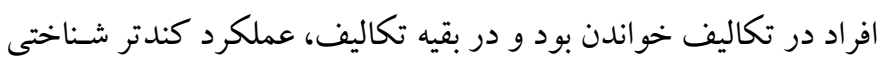

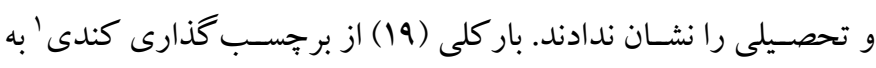

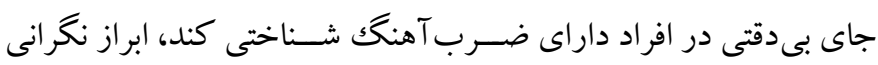

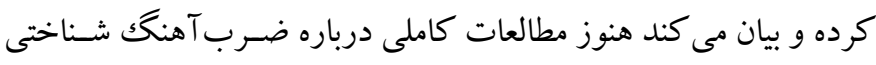

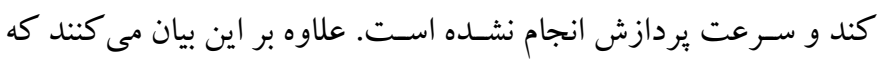
سرعت بردازش و توجه انتخابى اين افراد، آسيب ديده است.

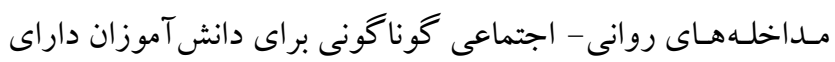

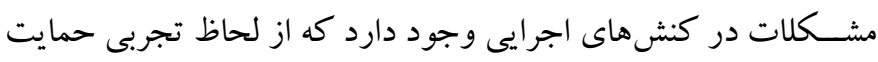

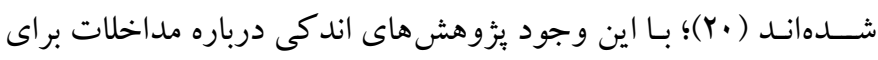

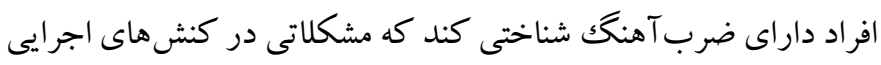
نيز دارند، انجام شده است. روش هاى مداخلهاى مختلفى مانند درمانهاى

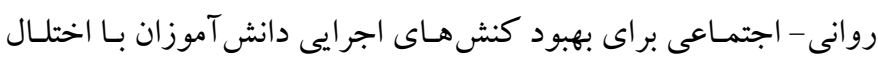

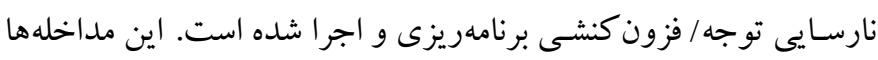

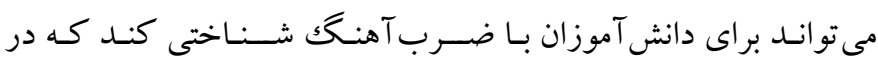

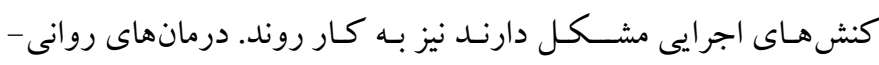

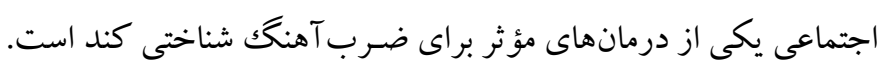

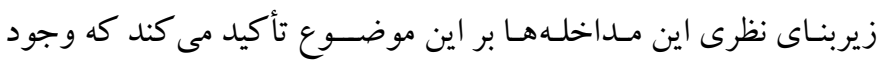

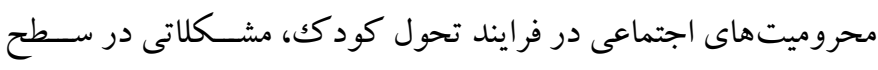
رفتارى، شـناختى، و اجتماعى - هيجانى كود كك ايجاد مى كند (Y) (Y). بايد

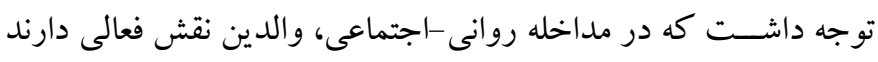

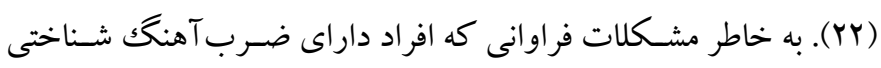

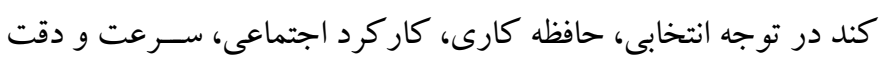

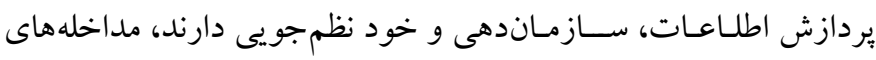

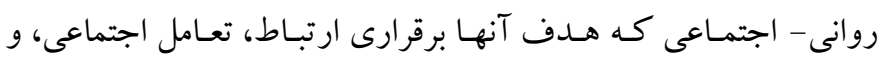
انعطاف يذيرى فكر و رفتار اسـت، ممكن اسـت در بهبود نشـانه هاى آنها مؤثر باشـــ. محور هاى اساسى مداخله روانى -اجتماعى شامل تغيير رفتار،

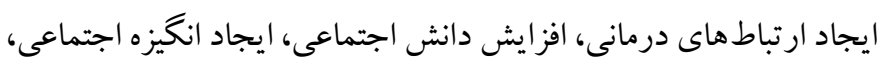

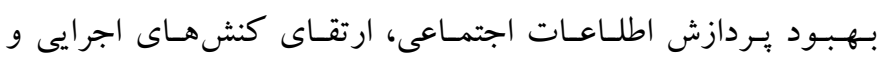

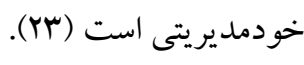


(KL)

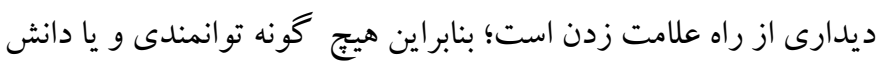

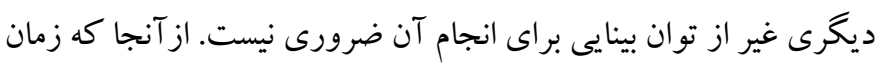

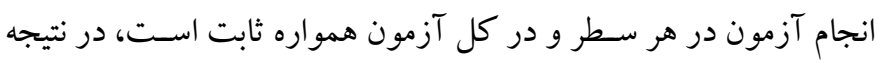

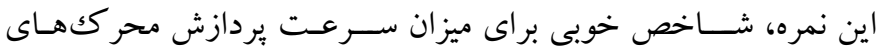

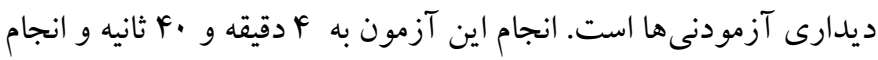

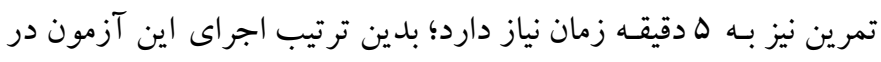

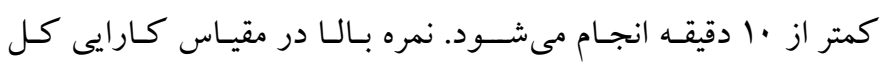

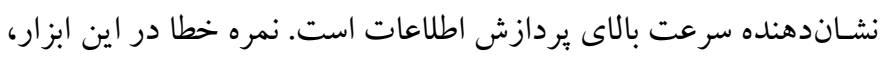
شاخصى براى تلاشمندى معرفى شده است و نمره خطاى بالا، نشاندهنده

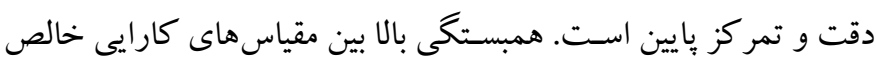
(GZ-F)

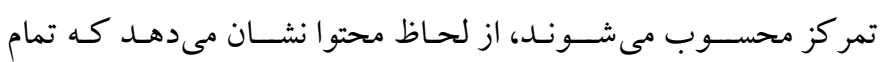
شـاخص ها، جنبههاى مختلف يكك سـازه واحد در آزمون d2 هسـتـند.

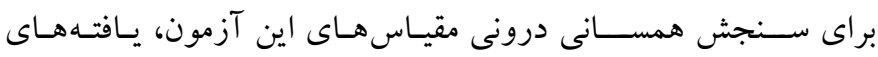

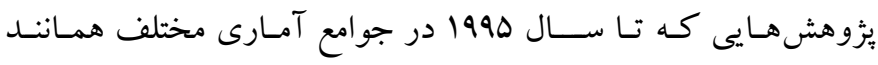

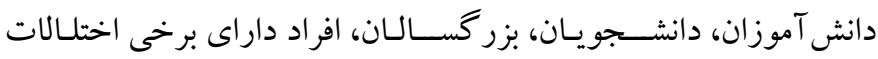

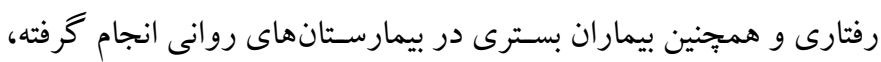

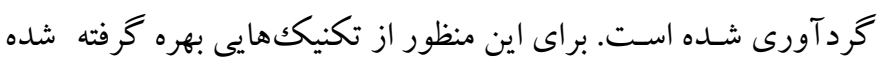

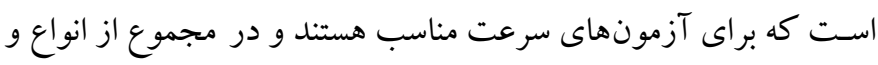

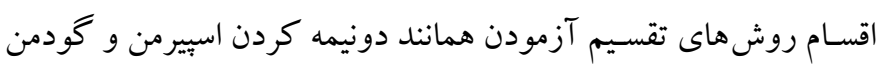

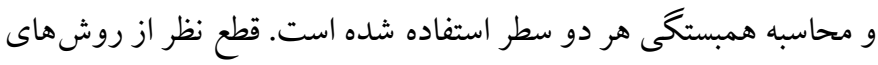

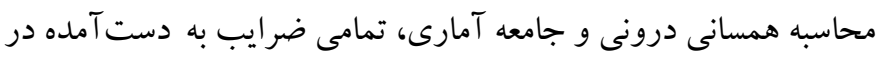

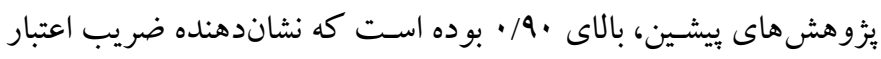

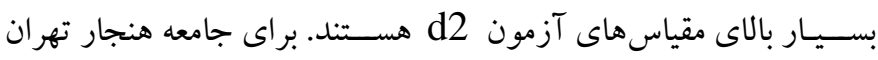

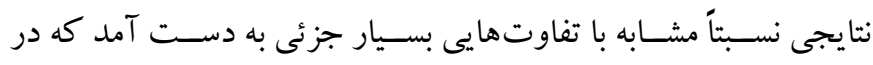

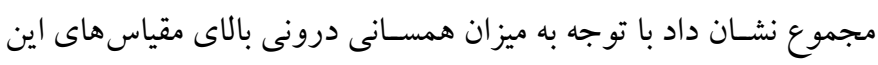

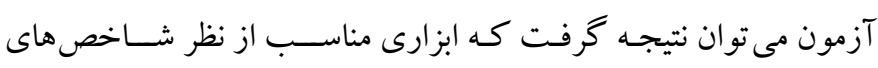

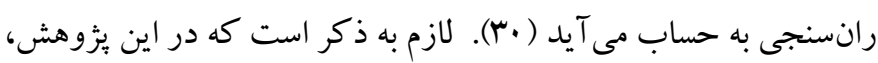
همسانى درونى اين آزمون بر اساس ضريب آلفاى كرونباخ، هـ/ • • بود.
شــاختى كند شــناخته شـــند. در مرحله بعد براى والدين اين تعداد از دانش آموزان، برسشنامه تشخيصى ضرب آهنگك شناختى كند، ارسال شد.

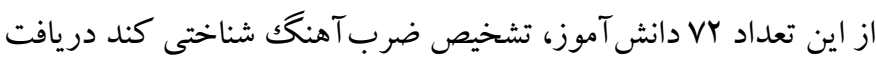

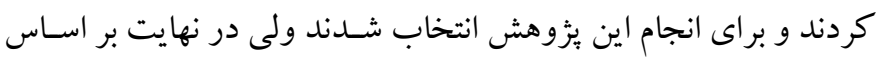

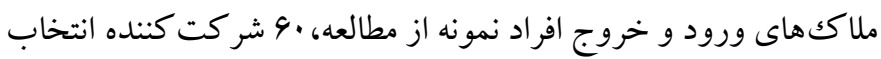

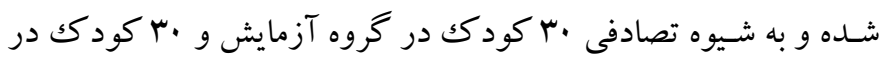

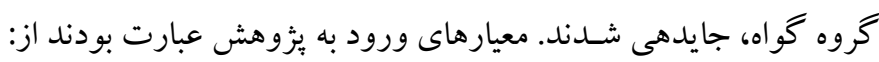

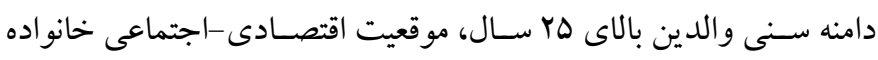
كود كك در حد متوسط، و تحصيلات والدين از سطح دييلم به بالا. لازم به ونه

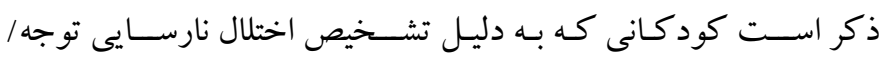

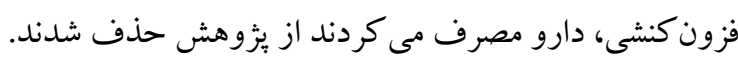

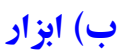

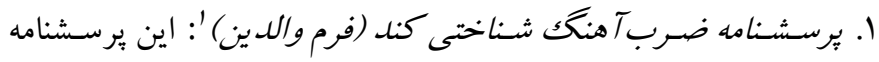

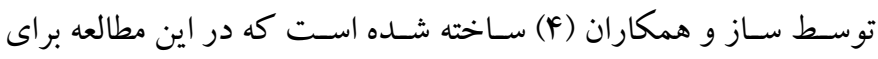
شـناسـيى و تشخيص كود كان داراى ضرب آهنك شناختى كند استفاده

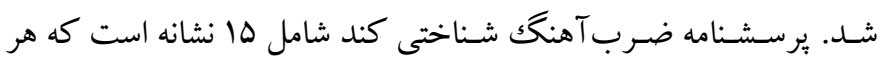

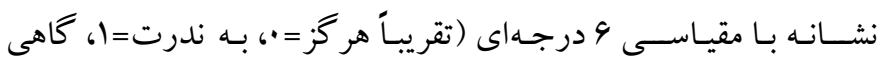

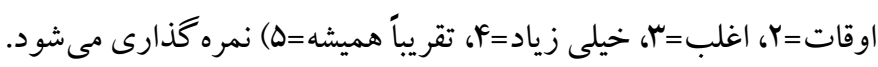

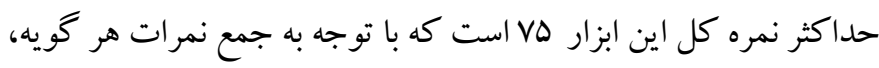

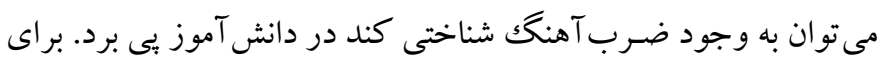

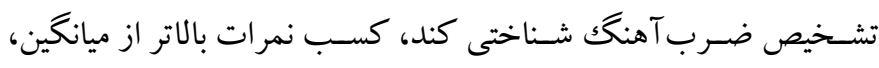

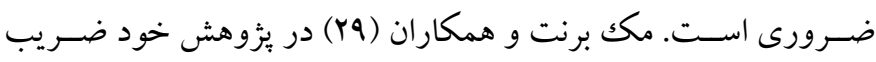

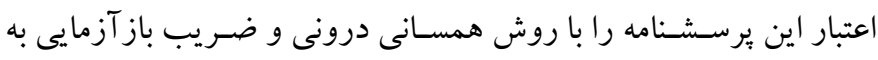

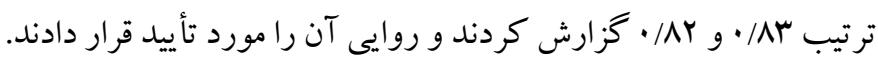
در اين يُوهش ضريب همسانى درونى اين برسشنامه با استفاده از ضريب آلفاى كرونباخ AF/ • به دست آمد. r. Tزمون توجه بريكنكامبّ": اين ابزار توسط بريكنكام در كشور آلمان

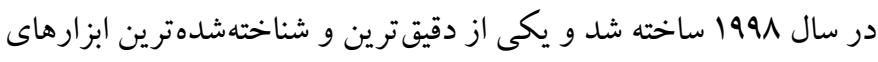

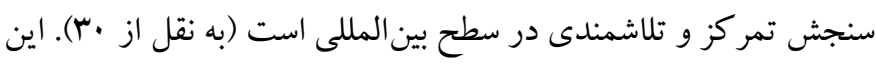

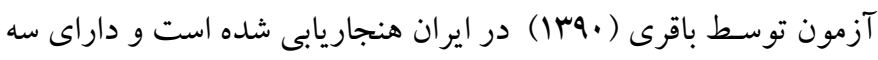

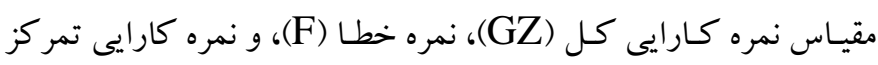




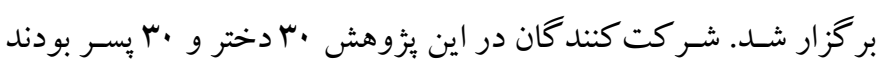

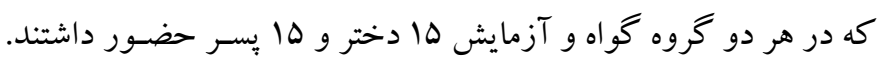

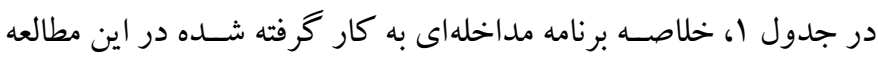

ارائه شده است.
ج) برنامه مداخله: در اين يثزوهش از روشهاى درمانى كودك محور

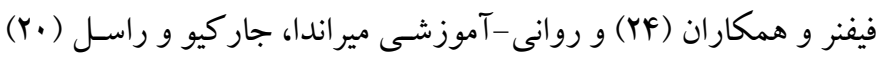

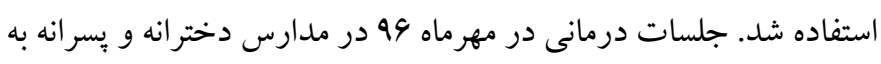

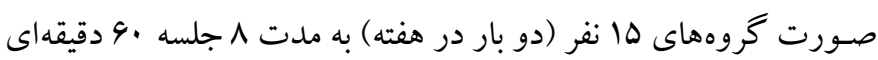

جدول 1: معرفى برنامه مداخله جهت افزايش سرعت و دقت يردازش اطلاعات

\begin{tabular}{|c|c|c|}
\hline محتوا & هدف & جلسات \\
\hline ايجاد محيطى بدون تنيدگى، آموزش درباره ويز گىهاى كود كان داراى ضرب آهنك شناختى كند و مشكلات خانو ادههاى آنها، آموزش درباره & رابطه درمانى & 1 \\
\hline 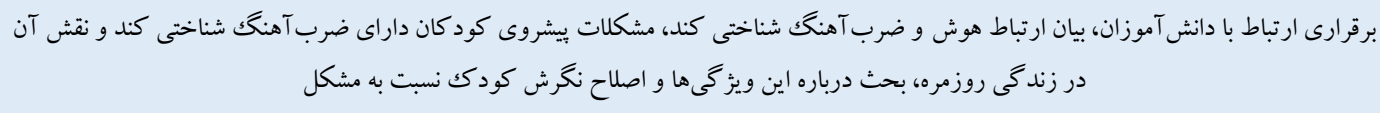 & ضرب آهنك شناختى با مشكل و ماهيت & r \\
\hline 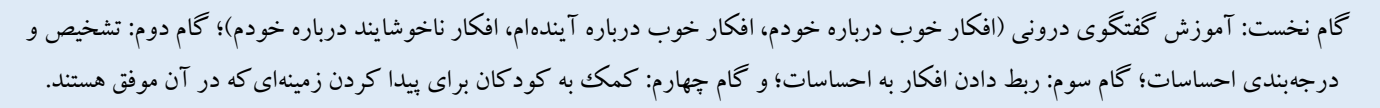 & كمكك به ايجاد اعتماد به خود & $r$ \\
\hline 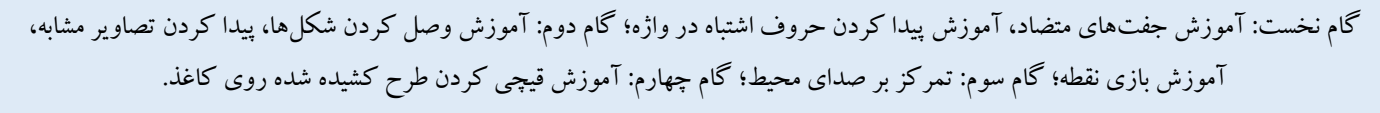 & 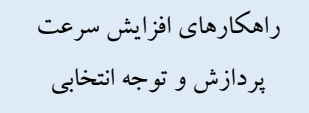 & f \\
\hline 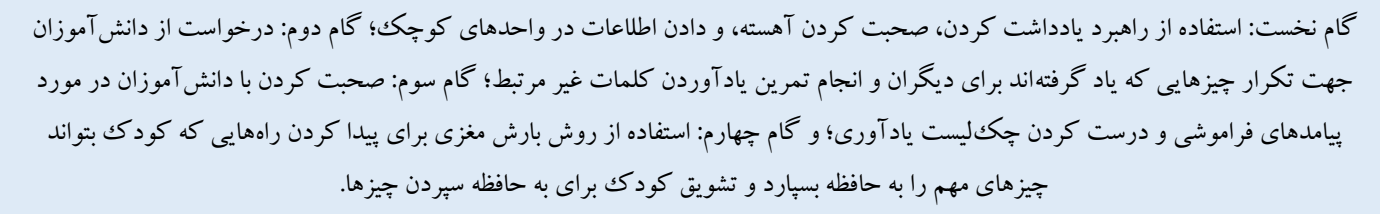 & 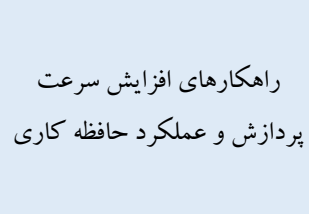 & $\Delta$ \\
\hline 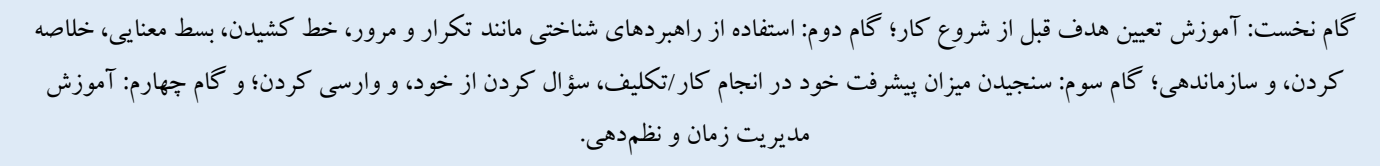 & آموزش خود مديريتى (خود & 4 \\
\hline 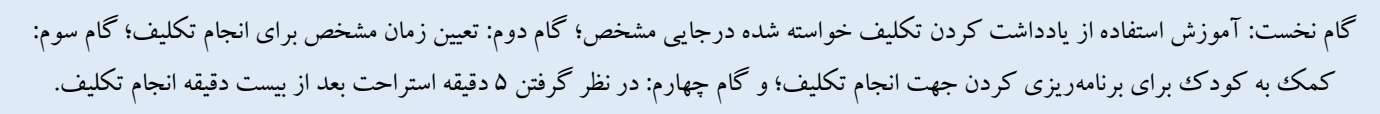 & آموزش راهبرد براى تكميل & $\checkmark$ \\
\hline 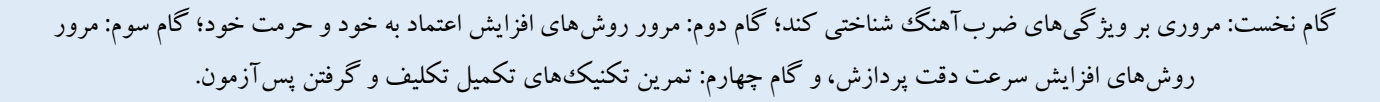 & مرور مطالب جمعبندى & $\wedge$ \\
\hline
\end{tabular}

مــاخلـهاى دريـافت نكردند و بعد از بِيانان اين مطالعه، مداخله مورد نظر براى گروه گواه نيز به طور مختصـر ارائه شـــ. لازم به ذكر اسـت سـاير ملـاحظـات اخلـاقى مـانند محرمانه ماندن اطلاعات و يا حق انصـــراف از شــركت در مطالعه در هر مرحله در اين بزؤهش رعيات شــد. در پيايان دادههاى به دسـت آمده با اسـتفاده از شـاخص هاى توصـيفى ميانگين و انحر اف استاندارد و روش استنباطى تحليل كوواريانس، تجزيه و تحليل
د) روش اجرا: براى اجراى اين مطالعه ابتدا با هماهنگى اداره آموزش و يرورش شهر تهران، به • 1 مدرسه ابتدايى دولتى (دخترانه و بسرانه) منطقه لم مراجعه شــد و افراد نمونه بر اسـاس شـرحى كه در بخش نمونه كيرى ارائه شـد، انتخاب شدهاند. سُبس بعد از بيان توضيحات لازم، از كود كان شـركت كننده در بثزوهش خواستهه شد كه برسشنامههاى بيش آزمون اين مطالعه را تكميل كنند. در مرحله بعد، اجراى مداخله توســ ئزوهشــر (دو بـار در هفته) به صــورت گرووهى انجام شــد. كروه آزمايش تحت آموزش (مـداخلـه روانى -اجتماعى) به مدت ^ جلســه ،و دقيقهاى و دو جلسـه ارزيابى درمان قرار گرفتند، در حالى كه دانش آموزان گرووه گو اه، 
نرمال بودن توزيع متغيرها در گروهها گزارش شـده است. با توجه به اين

يافتهها

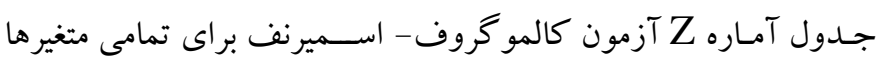

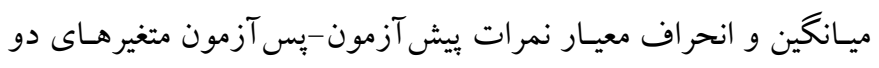

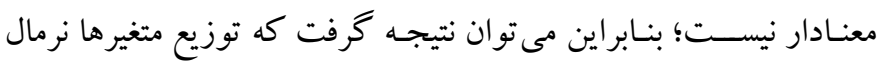

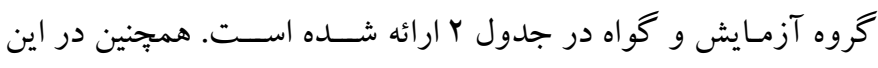

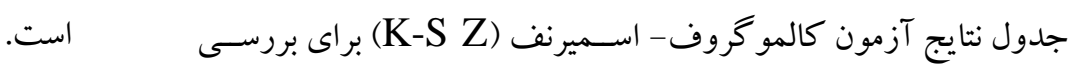

\section{جدول r: شاخصهاى توصيفى نمرات بيش آزمون-بيس آزمون در دو كروه آزمايش و كواه ((تعداد: • 7)}

\begin{tabular}{|c|c|c|c|c|c|c|}
\hline $\mathbf{p}$ & K_Z S & انحراف معيار & ميانكين & كروه & وضعيت & متغير \\
\hline . /ArG &.$/ 94$ & $11 / 99$ & $r q v / \cdot r$ & آزمايش & \multirow{2}{*}{ بيش آزمون } & \multirow{4}{*}{ سرعت يردازش } \\
\hline$\cdot / 9 \cdot 4$ & - NGF & $M / r r$ & rON/9 & كواه & & \\
\hline.$/ 9 \mathrm{TV}$ & . ND & $11 / 94$ & $M / 9 / . r$ & آزمايش & \multirow{2}{*}{ يس آزمون } & \\
\hline . /AG &.$/ 9.1$ & $\wedge 1 / \vee q$ & $r \Lambda \cdot / T V$ & كواه & & \\
\hline - /apq & •/Or & $V \cdot / \wedge \Delta$ & $r r \cdot / \Delta V$ & آزمايش & \multirow{2}{*}{ بيش آزمون } & \multirow{4}{*}{ كارايى خالص } \\
\hline . $/ \Delta Y r$ & ·/NIF & 9.19 & $r r r / . r$ & كواه & & \\
\hline . /AFY & $\cdot / \Delta r$ & $9 \mathrm{~V} / . \mathrm{r}$ & $r r \Delta / F r$ & آزمايش & \multirow{2}{*}{ بِس آزمون } & \\
\hline . /9MF & - NEG & $9 q / 1 r$ & rYq/av & كواه & & \\
\hline.$/ 991$ & . & FV/VD & $91 / 9 \mathrm{~V}$ & آزمايش & \multirow{2}{*}{ يشي آزمون } & \multirow{4}{*}{ كارايى تمركز } \\
\hline . VAG & $.19 \Delta F$ & $\Delta \Delta / F T$ & $9 \mathrm{~V} / \mathrm{F}$ & كواه & & \\
\hline.$/ 909$ & . NTr & $\Delta 1 / \Delta 9$ & 11r/Ir & آزمايش & \multirow{2}{*}{ پِس آزمون } & \\
\hline .19. & . N99 & Fr/NT & $Q F / 9 \%$ & كواه & & \\
\hline
\end{tabular}

برابر اسـت. نتايج آزمون باكس براى بررسى برابرى ماتريس كوواريانس

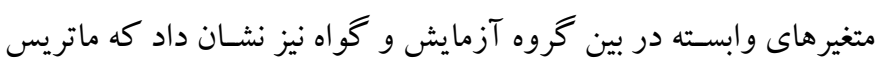

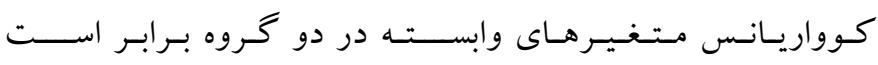
(BOX M=ll/rr،F=l/V،p>•/.9v)

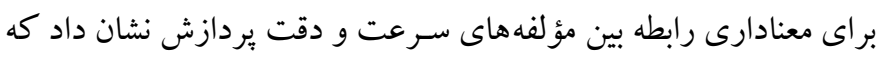

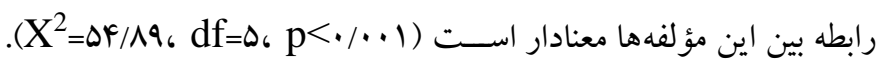
بس از بررسـى بيشفرضهـاى تحليل كوواريـانس جنـدمتغيرى، نتايج

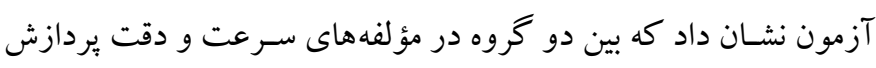

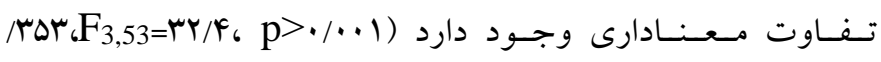

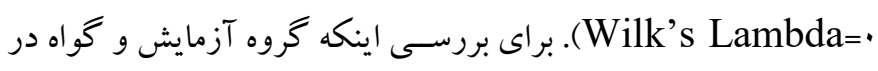

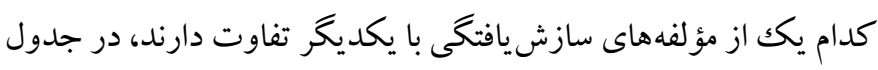
بانتايج تحليل كواريانس تككمتغيرى كزارش شده است.
براى بررسـى تأثير مداخله روانى - اجتماعى بر ســرعت بردازش،

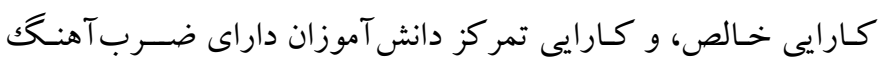
شـناختى كند از تحليل كوواريانس جندمتئيرى استفاده شد. نتايج آزمون بررسـى همخنى شـيب رگر ســيون بيش آزمون و بس آزمون مؤلفههاى سـرعت و دقت يُردازش (سـرعت يردازش، كارايى خالص، و و كارايى

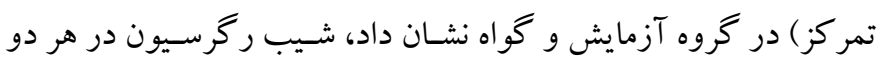

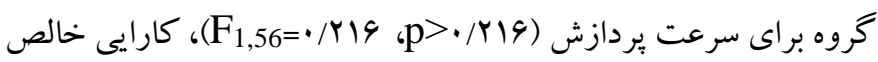

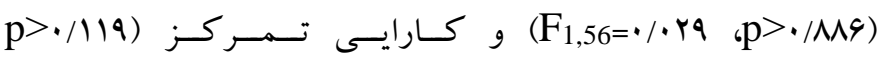

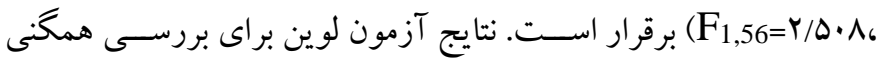

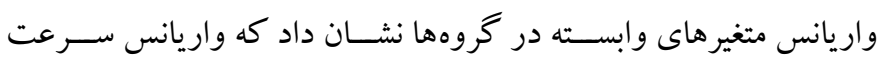
p>-/919 (F)

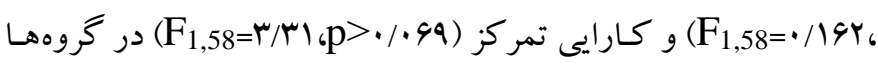


جدول بّ: نتايج تحليل كوواريانس ككمتغيرى تفاوت كروه آزمايش و كواه در مؤلفههاى سازشيافتكى

\begin{tabular}{|c|c|c|c|c|c|c|c|}
\hline اندازه اثر & $\mathbf{p}$ & $\mathbf{F}$ & خطاى استاندارد & تفاوت كروهها & ميانكين & كروه & متغير \\
\hline$\cdot / \cdot M$ &.$/ \cdot r \Delta$ & L & $1 Y / 9$ & Y१/१९ & $\begin{array}{l}\text { MIF/qq } \\
r A F / V .\end{array}$ & كو كاه & سرعت يردازش \\
\hline$\cdot / 11$ &.$/ \cdot 1 r$ & $\Delta / A r$ & $1 \cdot / \pi \Lambda$ & $\mathrm{TV} / \mathrm{IF}$ & $\begin{array}{l}\text { YFQ/WV } \\
\text { rYY/GY }\end{array}$ & كوزاه & كارايى خالص \\
\hline$\cdot / Y Y A$ & .1 .04 & $\Lambda / \cdot F \Delta$ & $\mathrm{V} / \mathrm{MA}$ & rY/rD & $\begin{array}{l}11 \Delta / .9 \\
9 T / V .\end{array}$ & كو آزمايش & كارايى تمركز \\
\hline
\end{tabular}

نيز در مطالعه خود در يزوهش خود هنگحامى كه مرحله بيخيرى را انجام

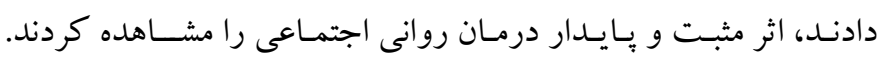

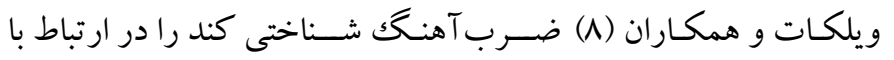

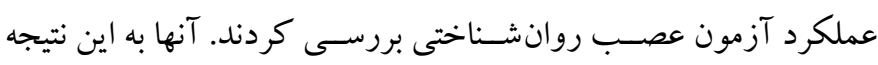

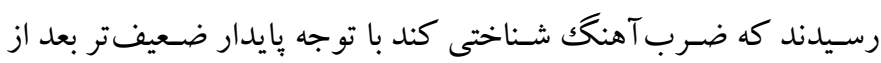

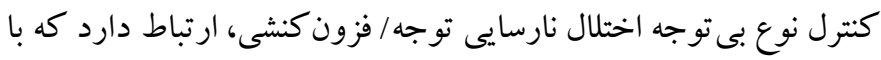
يافتهاى اين مطالعه تقريباً همسو است.

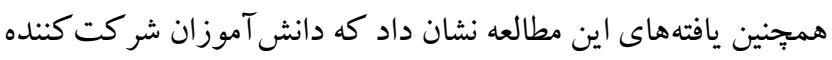

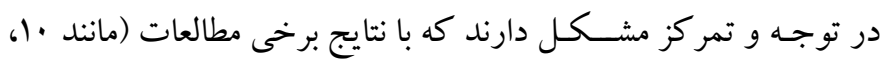

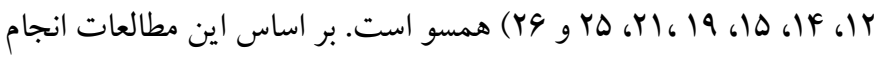

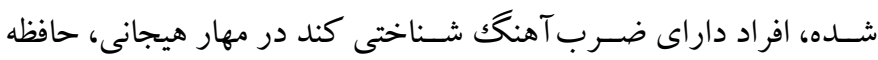

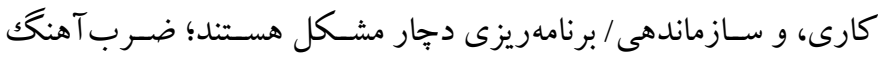

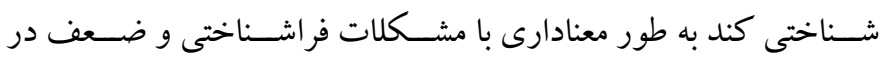

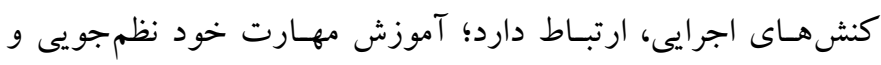
تقويت حافظه كارى كه از كنشهاى اجرايى هسـتند بر سـرعت و دوقد إنت

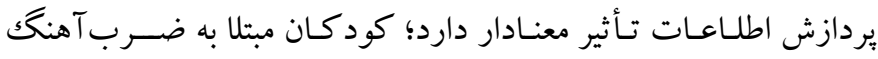
شناختى كند، به صورت دقيق عمل نمى كنند و تكاليف عصبش بناختى را

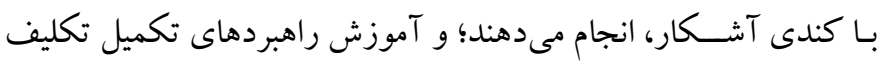

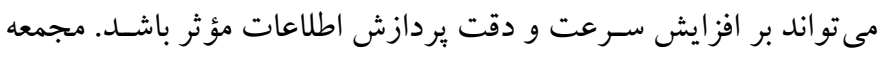
اين نتايج به طور ضمنى و مستقيم با نتايج مطالعه حاضر همسو هستند.

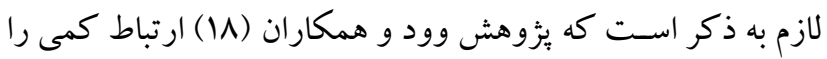
بين ضرب آهنگك شناختى كند و سرعت بردازش نشان دادند. همجنين در

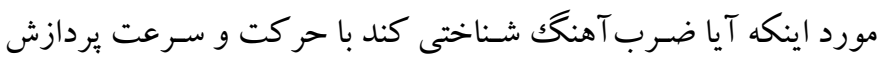
كندتر بعد از كنترل اختلال نارسـيى توجه / فزون كنشى ارتباط دارد يا نه،
با توجه به جدول ب آماره F براى مؤلفه هاى سرعت يردازش (س/ م/ه)

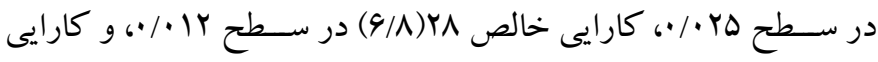

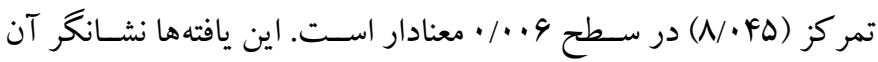

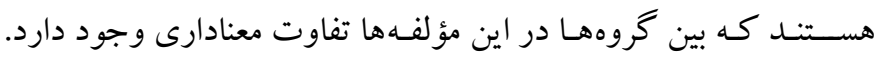

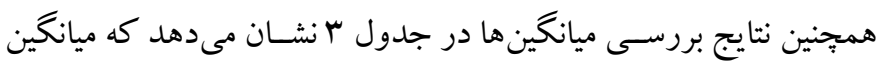

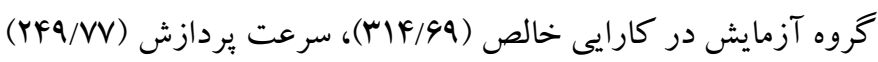

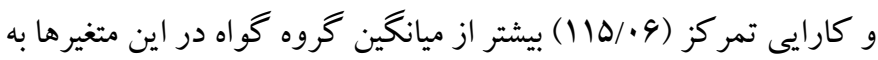

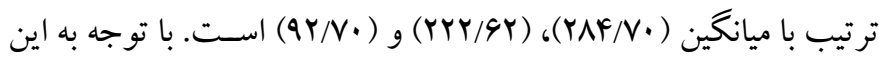

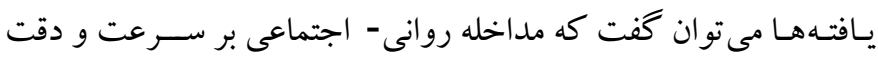

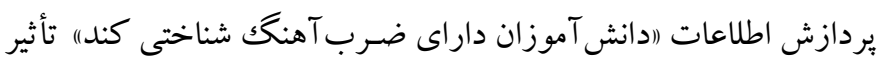

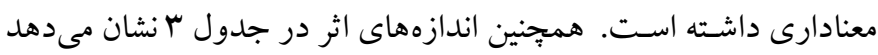

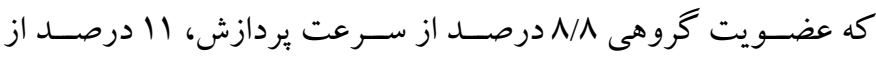

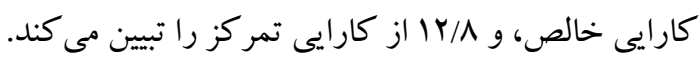

\section{بحث و نتيجه كيرى}

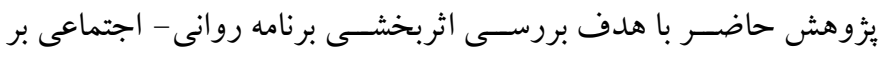

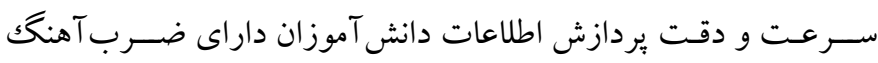
شـناختى كند انجام شــــ نتايج نشــان داد كه برنامه توانبخشسى روانى اجتمـاعى بـه افزايش ســرعت و دقت بردازش اطلاعات كودكان داراى

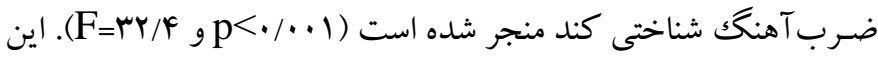

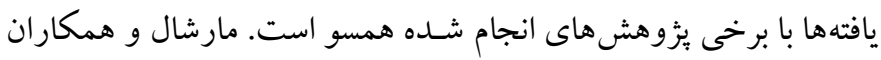

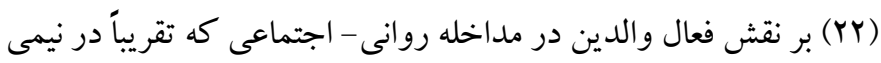

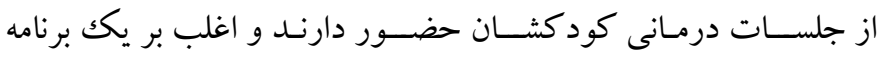

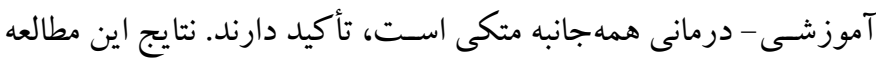

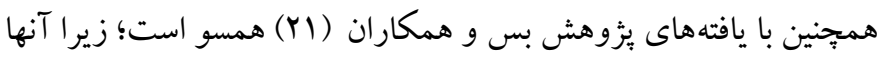


نهايت تدوين برنامه مداخلهاى براى كود كان داراى ضـربآهنگك شناختى كند برداشته است.

ضـرب آهنك شـناختى كند، اختلالى مستقل از نارسايى توجه / فزون

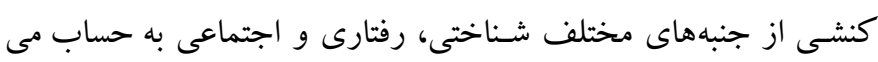

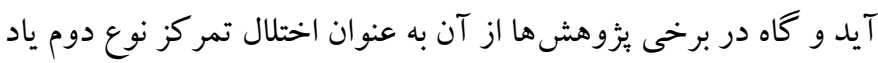

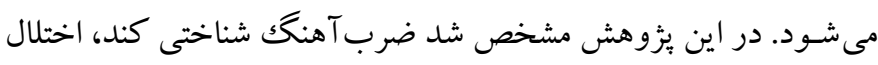

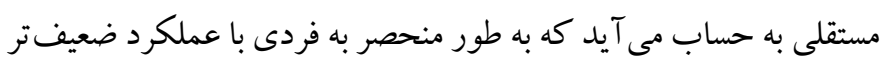

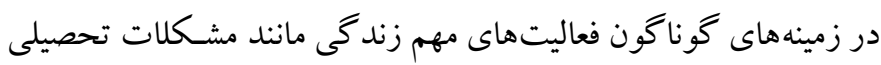

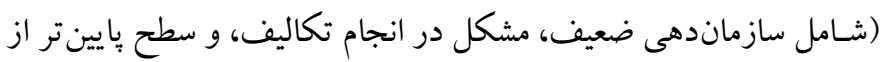

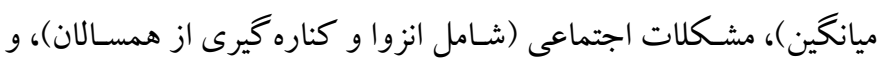
عدم تنظيم هيجانى ارتباط دارد و در جهت تاييد فرضـيه بار كلى مبنى بر

وجود اختلالى مستقل از نارسايى توجه/فزون كنشى صحه مى كذارد.

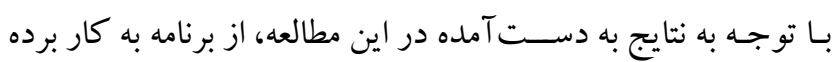

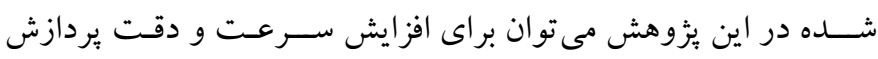

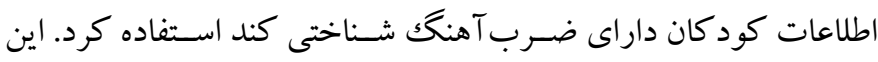
درمان همجنين در كنار روى آورد شــناختى رفتارى مى تو اند تا حدودى هـى داري

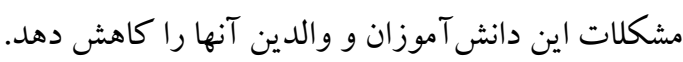

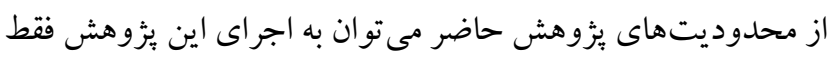

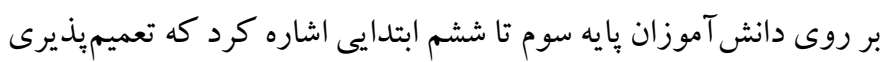

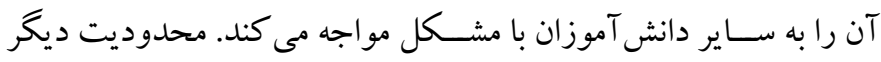

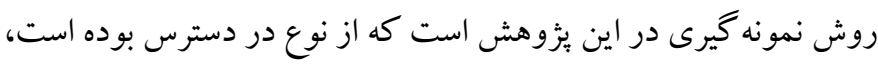

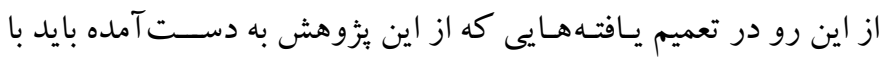

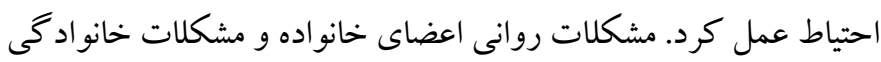

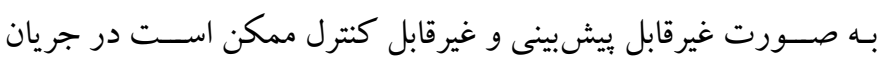

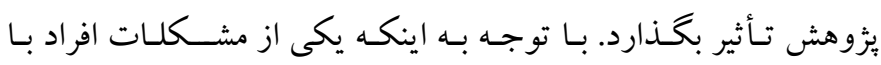
ضرب آهنك شـناختى كند، مشكلات اجتماعى و هيجانى است، بيشنهاد مىشود در يُزوهش هاى آتى به اين حيطه يرداخته شود و درمانهاى مؤثر

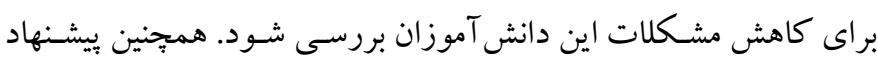

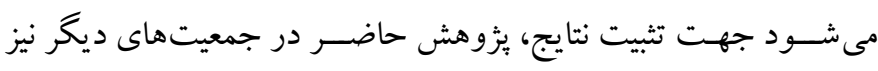

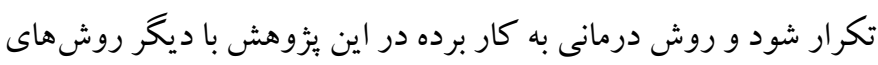

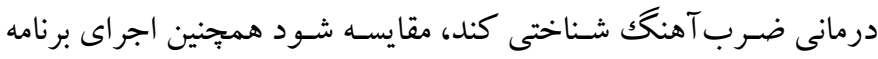

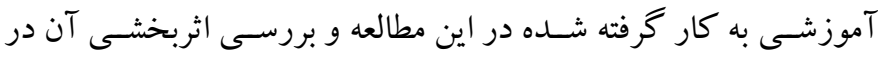

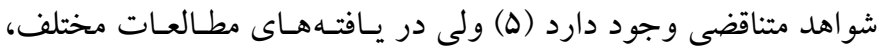
سرعت پردازش كند در بين شركت كنند گان با ضرباهنگك شناختى كند، كزارش شده است. نتيجه به دست آمده را مى توان بر اساس نتايج مطالعاتى مانند (N)، If

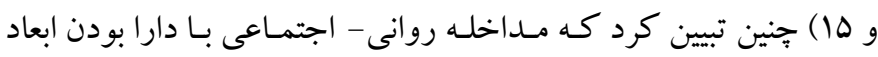

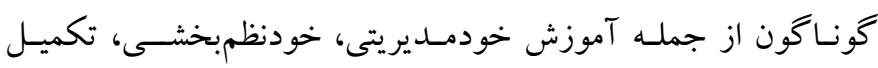
تكليف، و راهكارهـايى براى افزايش اعتمـاد به خود كود كان، مى تواند

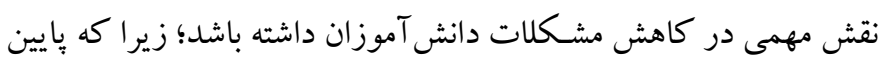

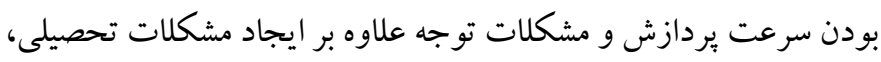

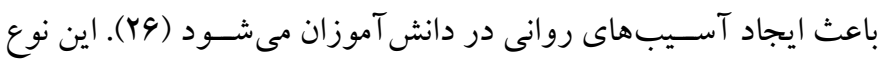

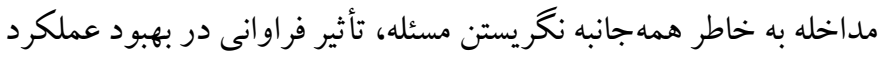

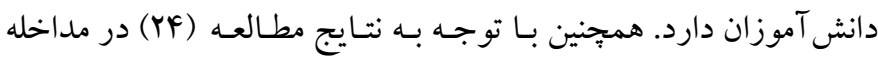

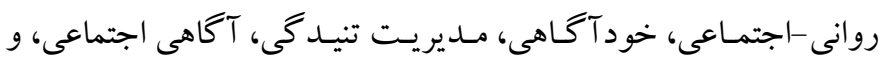

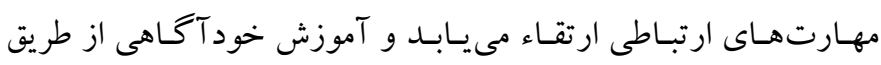

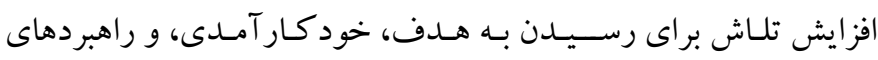

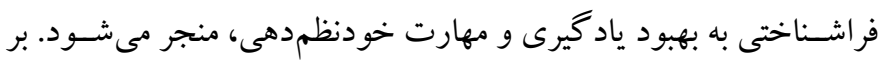

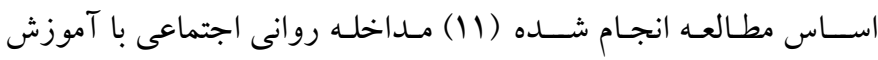

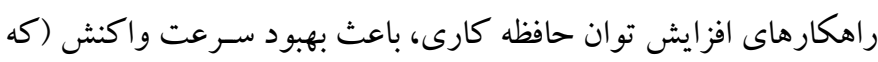

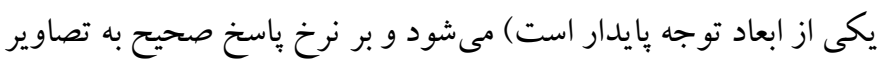

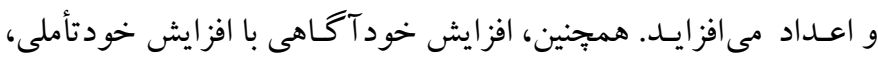

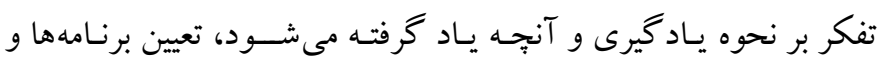

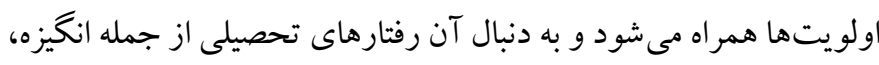
تو جه و عملكرد تحصيلى بهبود مى يابد.

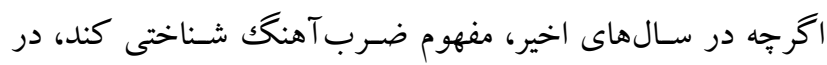
حوزه روانشـناسـى مرضسى تحولى و روانيزشـكى كودكى و نوجوان بيشـتر مورد توجه قرار گرفته اسـت، اما اين موضسوع همجنان مفهوم جديدى در ايران به حسـاب مى آيد و يزوهشه هاى كمى در اين حيطه

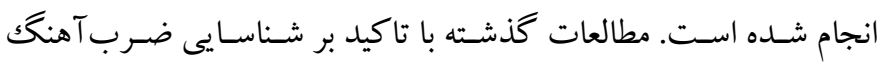

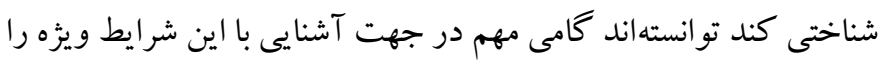

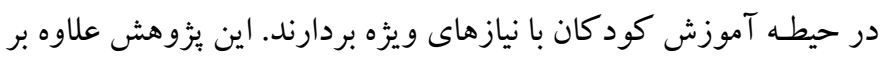

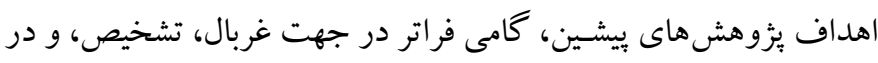




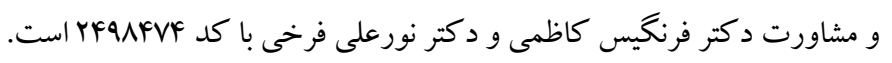

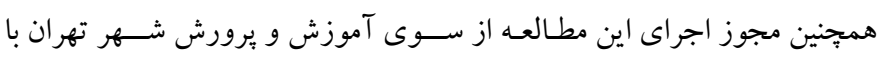

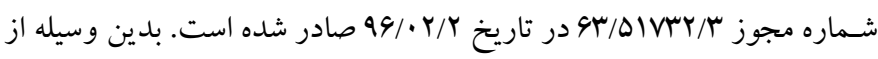
تمامى افرادى كه در اين مطالعه مشار كت داشتهاند، تشكر و قدردانى مى كنم. تضاد منافع: بدينوسيله اعلام مىشود كه اين مطالعه هيج گونه تضاد منافعى را

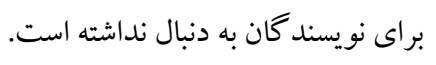

ديخر گروههاى كود كان با نيازهاى ويزه مى تواند تأثير گذار باشـــــ علاوه

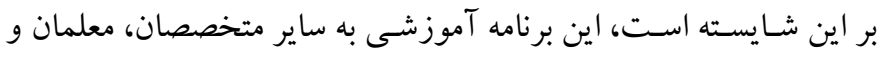

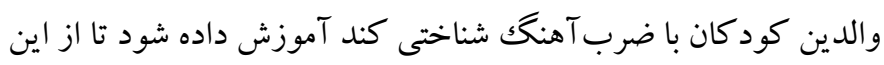

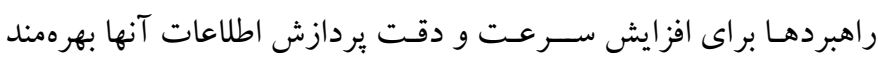
شوند. تشكر و قدردانى: اين يُوهش بر گرفته از رساله دكتراى خانم ليلا هميوند در

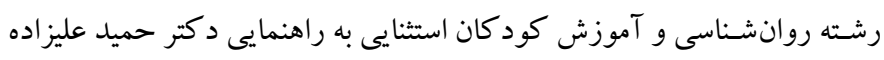




\section{References}

1. Becker SP. Sluggish cognitive tempo and peer functioning in school-aged children: a six-month longitudinal study. Psychiatry Res. 2014; 217(12):72-78. [Link]

2. Barkley RA. Distinguishing sluggish cognitive tempo from ADHD in children and adolescents: executive functioning, impairment, and comorbidity. J Clin Child Adolesc Psychol. 2012; 42(2):161-173. [Link]

3. Barkley RA. Sluggish cognitive tempo (concentration deficit disorder?): current status, future directions, and a plea to change the name. J Abnorm Child Psychol. 2014; 42(1):117-125. [Link]

4. Sáez B, Servera M, Burns GL, Becker SP. Advancing the multi-informant assessment of sluggish cognitive tempo: Child self-report in relation to parent and teacher ratings of SCT and impairment. J Abnorm Child Psychol. 2019 Jan 15; 47(1):3546. [Link]

5. Bauermeister JJ, Barkley RA, Bauermeister JA, Martínez JV, McBurnett K. Validity of the sluggish cognitive tempo, inattention, and hyperactivity symptom dimensions: neuropsychological and psychosocial correlates. J Abnorm Child Psychol. 2012; 40(5): 683-697.[Link]

6. Garner AA, Marceaux JC, Mrug S, Patterson C, Hodgens B. Dimensions and correlates of attention deficit/hyperactivity disorder and sluggish cognitive tempo. J Abnorm Child Psychol. 2010; 38(8):10971107.[Link]

7. Cook NE, Braaten EB, Vuijk PJ, Lee BA, Samkavitz AR, Doyle AE, Surman CB. Slow Processing Speed and Sluggish Cognitive Tempo in Pediatric AttentionDeficit/Hyperactivity Disorder: Evidence for Differentiation of Functional Correlates. Child Psychiatry \& Human Development. 2019 Dec 1; 50(6):1049-57.[Link]

8. Willcutt EG, Chhabildas N, Kinnear M, DeFries JC, Olson RK, Leopold DR, et al. The internal and external validity of sluggish cognitive tempo and its relation with DSM-IV ADHD. J Abnorm Child Psychol. 2014; 42(1):21-35. [Link]

9. Skirbekk B, Hansen BH, Oerbeck B, Kristensen H. The relationship between sluggish cognitive tempo, subtypes of attention-deficit/hyperactivity disorder, and anxiety disorders. J Abnorm Child Psychol. 2011; 39(4):513-525. [Link]

10. Araujo Jiménez EA, Jané Ballabriga MC, Bonillo Martin A, Arrufat FJ, Serra Giacobo R. Executive functioning in children and adolescents with symptoms of sluggish cognitive tempo and ADHD. J Atten Disord. 2015; 19(6):507-514. [Link]

11. Becker SP, Langberg JM, Luebbe AM, Dvorsky MR, Flannery AJ. Sluggish cognitive tempo is associated with academic functioning and internalizing symptoms in college students with and without attention-deficit/hyperactivity disorder. J Clin Psychol. 2014; 70(4): 388-403. [Link]

12. Mueller AK, Tucha L, Koerts J, Groen Y, Lange KW, Tucha O. Sluggish cognitive tempo and its neurocognitive, social and emotive correlates: a systematic review of the current literature. $\mathrm{J}$ Mol Psychiatry. 2014; 2: 5. [Link]

13. Moruzzi S, Rijsdijk F, Battaglia M. A Twin study of the relationships among inattention, hyperactivity/impulsivity and sluggish cognitive tempo problems. J Abnorm Child Psychol. 2014; 42(1):63-75. [Link]

14. Tamm L, Brenner SB, Bamberger ME, Becker SP. Are sluggish cognitive tempo symptoms associated with executive functioning in preschoolers? Child Neuropsychol. 2018; 24(1):82-105. [Link]

15. Baytunca MB, Inci SB, Ipci M, Kardas B, Bolat GU, Ercan ES. The neurocognitive nature of children with ADHD comorbid sluggish cognitive tempo: might SCT be a disorder of vigilance? Psychiatry Res. 2018; 270:967-973. [Link]

16. Smith ZR, Langberg JM. Predicting academic impairment and internalizing psychopathology using a multidimensional framework of sluggish cognitive tempo with parent- and adolescent reports. Eur Child Adolesc Psychiatry. 2017; 26(9):1141-1150. [Link]

17. Fassbender C, Krafft CE, Schweitzer JB. Differentiating SCT and inattentive symptoms in ADHD using fMRI measures of cognitive control. NeuroImage: Clinical. 2015; 8:390-397. [Link]

18. Wood WLM, Potts HE, Lewandowski LJ, Lovett BJ. Sluggish cognitive tempo and speed of performance. J Atten Disord. 2017; 21(8):684-690. [Link]

19. Barkley RA. Sluggish cognitive tempo: a (misnamed) second attention disorder? J Am Acad Child Adolesc Psychiatry. 2016; 55(3):157-158. [Link]

20. Miranda A, Jarque S, Rosel J. Treatment of children with ADHD: Psychopedagogical program at school versus psychostimulant medication. [Tratamiento para niños con TDAH: Programa psicopedagógico en la escuela frente medicatión psicoestimulante.]. Psicothema. 2006; 18(3):335-341. [Link]

21. Bos KJ, Fox N, Zeanah CH, Nelson III CA. Effects of early psychosocial deprivation on the development of 
memory and executive function. Front Behav Neurosci. 2009; 3:16. [Link]

22. Marshall SA, Evans SW, Eiraldi RB, Becker SP, Power TJ. Social and academic impairment in youth with adhd, predominately inattentive type and sluggish cognitive tempo. J Abnorm Child Psychol. 2014; 42(1):77-90. [Link]

23. Lerner MD, White SW, McPartland JC. Mechanisms of change in psychosocial interventions for autism spectrum disorders. Dialogues Clin Neurosci. 2012; 14(3):307-318. [Link]

24. Pfiffner LJ, Yee Mikami A, Huang-pollock C, Easterlin B, Zalecki C, Mcburnett K. A. Randomized, controlled trial of integrated home-school behavioral treatment for ADHD, predominantly inattentive type. J Am Acad Child Adolesc Psychiatry. 2007; 46(8):1041-1050. [Link]

25. Jacobson L A, Geist M, E. Mark Mahone E. Sluggish Cognitive Tempo, Processing Speed, and Internalizing Symptoms: the Moderating Effect of Age. J Child Psychol Psychiatry. J Abnorm Child Psychol. 2018; 46(1): 127-135. [Link]
26.Breaux RP, Langberg JM, McLeod BD, Molitor SJ, Smith ZR, Bourchtein E, Green CD. The importance of therapeutic processes in school-based psychosocial treatment of homework problems in adolescents with ADHD. J Consult Clin Psychol. 2018 May; 86(5):427.[Link]

27. Jacobson LA, Geist M, Mahone EM. Sluggish cognitive tempo, processing speed, and internalizing symptoms: the moderating effect of age. Journal of abnormal child psychology. 2018 Jan 1; 46(1):12735. [Link]

28. Goh PK, Martel MM, Barkley RA. Clarifying ADHD and Sluggish Cognitive Tempo Item Relations with Impairment: A Network AnalysisJ Abnorm Child Psychol. 2020 May 22.[Link]

29. McBurnett K, Villodas M, Burns GL, Hinshaw SP, Beaulieu A, Pfiffner LJ. Structure and validity of sluggish cognitive tempo using an expanded item pool in children with attention-deficit/hyperactivity disorder. J Abnorm Child Psychol. 2014 Jan 1; 42(1):3748. [Link]

30. Bagheri F.Test of attention \& concentration. First edition. Tehran: Arjmand Publication; 2011, pp: 82-85. [Persian]. 